\title{
The Drosophila RNA-binding protein RBP1 is localized to transcriptionally active sites of chromosomes and shows a functional similarity to human splicing factor ASF/SF2
}

\author{
Young-Joon Kim, ${ }^{1}$ Ping Zuo, ${ }^{2}$ James L. Manley, ${ }^{2}$ and Bruce S. Baker ${ }^{1}$ \\ ${ }^{1}$ Department of Biological Sciences, Stanford University, Stanford California 94305 USA; $^{2}$ Department of Biological \\ Sciences, Columbia University, New York, New York 10027 USA
}

\begin{abstract}
An RNA-binding protein gene (rbp1) from Drosophila melanogaster, encoding an RNA recognition motif and an Arg-Ser rich (RS) domain, has been characterized. The predicted amino acid sequence of $r b p 1$ is similar to those of the human splicing factor ASF/SF2, the Drosophila nuclear phosphoprotein SRp55, and the Drosophila puff-associated protein B52. Northern and immunohistochemical analyses showed that rbp1 is expressed at all stages in all tissues and that the RBP1 protein is localized to the nucleus. Consistent with a role in mRNA metabolism, indirect immunofluorescence reveals that the RBP1 protein colocalizes with RNA polymerase II on larval salivary gland polytene chromosomes. RBP1 protein made in Escherichia coli was tested for splicing activity using human cell extracts in which ASF has been shown previously both to activate splicing and to affect the choice of splice sites in alternatively spliced pre-mRNAs. In these assays, RBP1 protein, like ASF, is capable of both activating splicing and switching splice site selection. However, in each case, clear differences in the behavior of the two proteins were detected, suggesting that they have related but not identical functions. The general nuclear expression pattern, colocalization on chromosomes with RNA polymerase II, the similarity to ASF/SF2, SRp55, and B52, along with the effect on alternative splicing shown in vitro, suggest that rbp1 is involved in the processing of precursor mRNAs.
\end{abstract}

[Key Words: RNA recognition motif; splicing factor; similarity to ASF/SF2; colocalization with RNA polymerase II]

Received June 10, 1992; revised version accepted October 14, 1992.

The diverse array of metabolic processes that RNA undergoes and the number of proteins involved in these processes suggest that there are many ways in which RNA is recognized by trans-acting factors. Among them, RNA recognition by proteins with the RNA recognition motif (RRM; for review, see Dreyfuss et al. 1988; Bandziulis et al. 1989; Mattaj 1989; Kenan et al. 1991) appears to be one of the major RNA-binding mechanisms. The family of proteins with RRMs now contains $>50$ members, and among the proteins in this family whose functions are known are proteins involved in the regulation of alternative splicing ( $S x$ l, Bell et al. 1988; tra-2, Amrein et al. 1988; Goralski et al. 1989; ASF/SF2, Ge et al. 1991; Krainer et al. 1991); transcription ( $L a$, Chambers and Keene 1985; rho, Pinkham and Platt 1983), splicing (U170K, Query et al. 1989; U1A, Sillekens et al. 1988; U2AF, Zamore et al. 1992; U2B"', Habets et al. 1985; PRP24, Shannon and Guthrie 1991); polyadenylation (PAP, Raabe et al. 1991; CstF64k, Takagaki et al. 1992); and translation (PAB, Sachs et al. 1986; elF-4B, Milburn et al. 1990; T4 gp32, Krisch and Allet 1982). In addition to these proteins, many heterogenous nuclear ribonuclear proteins (hnRNPs) also contain RRMs (e.g., Burd et al. 19891.

The mechanism of RNA recognition by the RRM is not understood, but several RRM sequences have been shown to have the specificity for recognizing a particular target. Thus a single RRM with minimal flanking sequence from poly(A)-binding protein (Sachs et al. 1987) or U1-70K (Query et al. 1989) protein is sufficient to specifically bind these proteins to its target RNAs. Furthermore, the sequence around RNP-1 has been shown to be responsible for the binding specificities of the U1A and U2B" proteins (Scherly et al. 1990; Bentley and Keene 1991). However, for the La (Chambers et al. 1988) and Ro-60K proteins (Deutscher et al. 1988), significant flanking sequences as well as the RRMs are required to reproduce the RNA-binding activity of the full-length 
proteins. Taken together, these data show that the RRM provides at least a portion of the RNA-binding activity of RRM-containing proteins.

The RNA-binding activity of the RRM and the number of RRM proteins involved in many aspects of RNA metabolism suggest that RRM-containing proteins are good candidates for RNA-processing regulators. Because many developmental processes are known to be regulated at the level of RNA processing and only a few genes have been identified that are involved in these processes, many as yet unidentified proteins, particularly RRM proteins, may participate in these processes. To identify new genes involved in RNA metabolism, we used degenerate polymerase chain reaction ( $\mathrm{PCR}$ ) to clone new members of the RRM gene family (Kim and Baker, 1993). Of the 12 different RRMs identified in this way, we found that two PCR-amplified fragments, RRMl and RRM11, had a similarity to the RRM of ASF/SF2 (Kim and Baker, 1993|, which acts as a general splicing factor as well as an alternative splicing factor in human cell extracts (Ge et al. 1991, Krainer et al. 1991).

Here, we report the isolation and characterization of the $r b p 1$ (Rna-binding protein 1) gene that encodes the RRM1 sequence. $r b p 1$ encodes a nuclear protein that has a high sequence similarity to the human splicing factor ASF/SF2. The RBPl protein is colocalized with RNA polymerase II on larval salivary gland polytene chromosomes. Consistent with a functional similarity to ASF/ $\mathrm{SF} 2$, in vitro splicing assays showed that the RBP1 protein affects splicing in a manner similar to, but distinct from, ASF/SF2. These results suggest that $r b p 1$ may play a role in pre-mRNA processing.

\section{Results}

\section{Cloning and characterization of $\mathrm{rbp} 1$}

To characterize the structure of the gene $(r b p 1)$ from which the RNA-binding domain RRMl is derived (Kim and Baker 1993), we used the RRMI DNA sequence as a probe to isolate five $r b p 1$ cDNA clones $(r b p 1-a,-b,-c,-d$ and $-e \mid$. The size of the insert in the $r b p 1-b$ clone was 2.0 $\mathrm{kb}$, whereas the size of the insert of all the other cDNAs was $\sim 0.7 \mathrm{~kb}$. Restriction mapping and sequencing of both $5^{\prime}$ and $3^{\prime}$ ends of these cDNA clones revealed that there are two types of cDNAs: $r b p 1-a$ type and $r b p 1-b$ type. The complete nucleotide sequences for the $r b p 1-a$ and $r b p 1-b$ cDNAs, as well as $r b p 1$ genomic DNA, were determined. Comparisons of the cDNA sequences to the genomic sequence revealed that the $r b p 1-a$ cDNA was composed of three exons and was generated by the removal of two introns. In the rbp1-b cDNA, both introns were retained in the cDNA, suggesting that it might represent an unspliced pre-mRNA (Fig. 1).

Of the four cDNAs that had poly(A) tails, all were polyadenylated 157 nucleotides past the stop codon that terminates the open reading frame, (ORF) and between a putative polyadenylation signal sequence, AAUAUAAA and possible downstream element that consists of a $T$ stretch (Fig. 2). Within 50 nucleotides, $3^{\prime}$ of this polyadenylation site, a closer match to the consensus poly- adenylation signal sequence AAUAAA and a downstream $\mathrm{T}$ stretch is found, but this polyadenylation signal was not used in the cDNAs that we characterized.

Although we have not determined the exact transcriptional initiation site, the fact that all cDNA clones from the two different libraries have their $5^{\prime}$ ends within 50 nucleotides of each other, and that the size of the rbp1-a type cDNA sequence without a poly $(\mathrm{A})$ tail $(0.75 \mathrm{~kb})$ and the size of the corresponding type A transcript measured from Northern analysis $(0.8 \mathrm{~kb})$ are about the same, suggests that the $5^{\prime}$-most cDNA sequence that we identified is not far from the authentic transcription initiation site. The first AUG of the largest ORFs of both the rbp1- $a$ and $r b p 1-b$ type cDNAs was found at +707 bp of the genomic sequence following many stop codons in all three frames (Fig. 2).

\section{RBP1 has a similarity to ASF/SF2, B52, and SRp55}

The largest ORF of the RBP1-a type mRNA encodes a 135-amino-acid protein (RBPl-a). The amino acid sequence encoded by this ORF shows two interesting motifs: an RRM in the amino-terminal two-thirds of the protein and an Arg-Ser-rich (RS) domain in the carboxyterminal one-third of the protein (Fig. 1).

Interestingly, the two distinctive motifs (an RRM and an RS domain) of the RBPI protein are also found together in the splicing factors, TRA-2, U1-70K small nuclear ribonucleoprotein (snRNP), ASF/SF2, a putative RNA-processing factor, SRp55, and a puff-associated protein, B52. Among these proteins the RRMs of ASF/SF2, SRp55 and B52 have high similarities to that of RBP1 (Fig. 3). The RRM of RBP1 shows $47 \%$ identity with that of ASF/SF2 and $37 \%$ identity with that of B52. Considering that $<20 \%$ identity is typically found from the comparison of two random RRMs, the $47 \%$ identity shown between these human and fly proteins is striking (Fig. 3a).

The high similarity between ASF/SF2 and RBP1 prompted us to analyze these two protein sequences using the COMPARE and DOTPLOT programs. These programs compare two protein sequences and plot the points where high matches are found. The computer analysis of ASF/SF2 and RBP1 protein sequences shows that RBP1 and ASF/SF2 protein sequences can be divided into two and four regions, respectively (Fig. $3 \mathrm{~b}$ ). RBP1 is divided into two regions. Region 1 (1-80 amino acids.) is an RRM, and region 2 (81-135 amino acids) is an RS domain. ASF/SF2 is divided into four regions: A, B, C, and $D$. Regions $A$ and $D$ have been identified as an RRM and RS domains, respectively (Ge et al. 1991, Krainer et al. 1991), and show very strong matches to those of RBP1. The nature of regions $B$ and $C$, which are present in ASF/SF2, SRp55, and B52, but not in RBP1, is unknown. However, computer analysis has revealed that $C$ has a similarity to the RRM of RBPl. Although region C does not show as strong a match as region $A$ to the RRM of RBP1, the amino acid sequences from 123 to 135 and from 149 to 175 of ASF/SF2 show substantial matches to the region of RNP-2 and RNP-1 consensus sequences of 
GAGCTCCGCC̈GCGGCGCCAGTTTCCTTGGGGACTCGCCTÄCCCTGGACCAंGCCAGTGCTTCTTGAAATGCCAGCCGATGTGCTGGCCACÄGAGAGTGTTC் GTCAGCCTCATTTAAGTTAGGATTTGCTTATGTTTTCGTTCAATGAAATGAAGCCCGGCGGACTGGTTATGAAACTCAGTGCTGCCAGATGGTGAGAGÄ

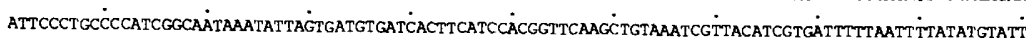

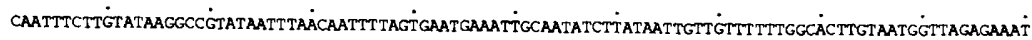

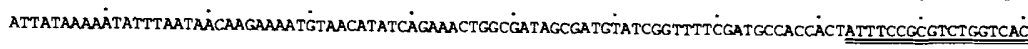
ACTITTCGGTAATTGTAATAAATAAAGGAAAGGCGGAGATTTTTGTTAAAATTTTAACAAAATTGGATGACATTTTAGAAGGTAAGTGGGAAATTAGTG

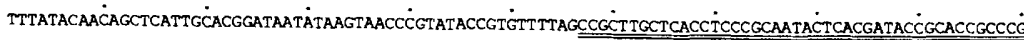
ACAAAAATGCGGCGATATAGGGGAGTGGGAC̈TTGGCCTGCAAGGTGTACGTGGGAACCTGGGCTCCTCGGCGTCCAAGCACGAGATAGAAGGCGCATTTC்

$M$ P R Y R E W D L A C K V Y V G N L G S S A S K K H E I E G A F A CCAAATATCGAACCCCTGCGAAACGTGTGGGGTGCCCGCAÄTCCACCAGGTTTCGCCTTTGTCGAATTTGAGGATCGCCGTGACGCGGAAGACGCAACGGC

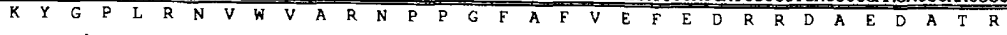
TCCCCTGGACGGAACACGCTGCTGCGCCACATAGGATTCGCGTAGAGATGTCTTCGGGTCGCTCGCGCGATCGCCGGCGCGGAGAAGGCGGCAGTAGTGG G E G G S S G CGCTCTGGTTCCGGACGCTACAGGTAATTCCACGACAAAAAACTGTACTTCTCATGTTÁCTTGGCTCAATGTGTCTCCCAAATGGAACAATGGATCACT $G R$ R $R$

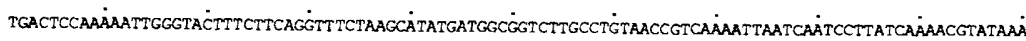
ATTTGTTATCGAAATTTCATTGGAATCGTCGGCAAAAAACATTAATTGCGAATAGCAAACA்TGTACATTTTCCCGCCTTTTTCTGCACGTGATAGAACAGC

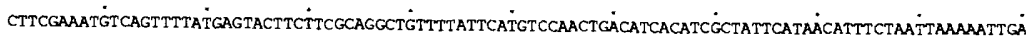
CTTGGTACTTTA'TTTAGACCAAACTTACAÄACTGTATACATATATTATCTACGATCCAA'CATTTAGTGGTTGTTAAATTCGAGTTATCGACACTTTTTC AGGATAACTCTTCGGCTAGAACTACTTCCÁCTGCTACTTCTTCCTTCTACAACATCAACAATCTACAACAGCAACCATCTTCACAGCCACAGCCAGCAAC

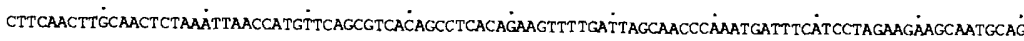

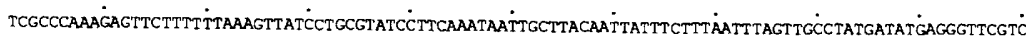

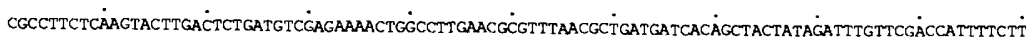

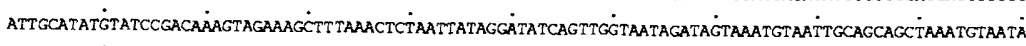

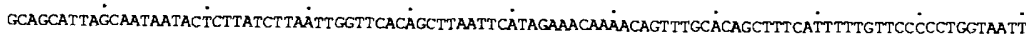

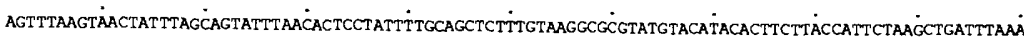
TAATTTTATTAAGCTTTTAÄGTAATCATTTCTTCTTTACCAATGCGTTTÄTTTCAGGTCACGTTCGCCACGTCGCTCCCGATCGCCCCC. S R S P R R R S P R R S F TCTCGCGCGATCGTCGAAGTCGCTCGGATTCTCGGGATCGTCATTAATGTTTCCAAAAGGATATCGTTTAAGCAGTGTCGCATCAAAGAACAAGCCGCCA $S R D R R S R S D S R$ D R H

AGGCCGTATTTTCTGTAGGAATTCCTATGTCGATTGCGATCCAAGTAAATTTACTTCAGÄTGCAATATAAATCTTTCGATGCATTCTTGAATCTTTTTI TTTTTTACTAAAAAATAAAGACGCACAACAGGCGAGTTTTGATTGGTTTCATATATATCAAAAACAGTTTGTTTCCAGCAAAACGGGACGTGCTTGTGCACं TgtTTATATGTGAGAATTGÄGTGCTGCTGTA 2632

Figure 1. The genomic nucleotide and predicted amino acid sequence of $r b p 1$. The nucleotide sequence of $r b p 1$ genomic DNA is shown. The three exons used in type-A transcript are double-underlined. The polyadenylation signal AATAATAAA is shown in italics. The amino acid sequence deduced from the DNA sequence is presented under the nucleotide sequence.

RBP1. In addition, the protein structure analysis using the PEPTIDESTRUCTURE and PLOTSTRUCTURE programs shows that each of these regions has a similar structure to that of RNP-1 and RNP-2, respectively (data not shown). Because the RRM itself is a very loosely conserved domain, with RNP-1 and RNP-2 being the most conserved sequences, the matches between region $\mathrm{C}$ and the RRM indicate that region $\mathrm{C}$ is a very weakly conserved RRM, which was not noticeable from a conventional pairwise comparison. A similarity between regions $A$ and $C$ has also been noted by Zahler et al. (1992), and support for the functional significance of this second RRM has recently come from mutational analysis of the ASF/SF2 protein (P. Zuo and J.L. Manley, in prep.). Region $\mathrm{B}$ also shows a weak similarity to the RS domain of $\mathrm{RBPl}$ in that there are four arginine and two serine residues present within the 22 -amino-acid region.

The largest ORF of $r b p 1-b$ cDNA uses the same AUG as the rbp1-a type mRNA. However, in the $r b p 1-b$ cDNA, a stop codon is present just 1 nucleotide after the 5 ' splice site of the retained second intron. Therefore, the ORF of $r b p 1-b$ encodes only the first 106 amino acids of the RBPl-a protein, including the RRM, but without most of the RS domain, and it encodes no amino acids unique to the RBPl-b protein. In this regard the coding capacities of $r b p 1$ again show a similarity to those of ASF/SF2. The ASF/SF2 gene also encodes several protein isoforms: ASF-1 has both the RRM and RS domains, whereas ASF- 3 has only the RRM without the RS domain (Ge et al. 1991).

\section{The developmental profile of the $\mathrm{rbpl} R N A$} and the expression of the RBP1 protein

Northern analysis of embryonic poly $(A)^{+}$RNA using the rbp 1- $a$ cDNA probe detected both 0.8- (type A) and 2.0$\mathrm{kb}$ (type B) RNAs. We believe that the type-A and type-B transcripts correspond to the rbp1-a and rbp1-b type RNAs identified in the cDNA analysis. The abundance of these transcripts relative to one another does not differ by more than two- to threefold (Fig. 2b).

A developmental Northern analysis revealed that these two transcripts are present in all developmental stages. However, larger transcripts were detected after the third instar larval stage (Fig. 4). The sizes of these late transcripts are between 2.7 and $5 \mathrm{~kb}$. Because the genomic Southern analysis with the same probe detected a single restriction fragment at a low stringent condition and the $2.0 \mathrm{~kb}$ transcript retained both introns found between the polyadenylation signal and the first exon defined by the sequences of five independently isolated $r b p 1$ cDNA clones, the larger transcripts that appeared after the third-instar larval period may represent bona fide $r b p 1$ transcripts produced from different promoters and/or polyadenylation sites at the later developmental stages. 
Kim et al.

a

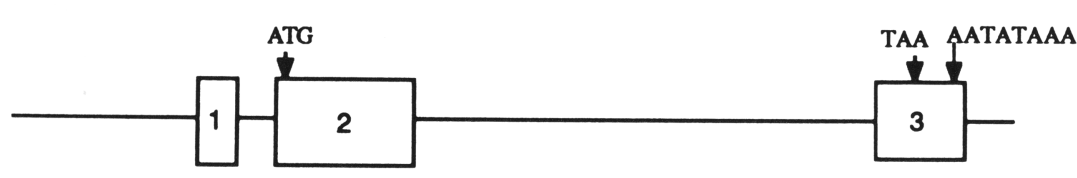

1. Type A.

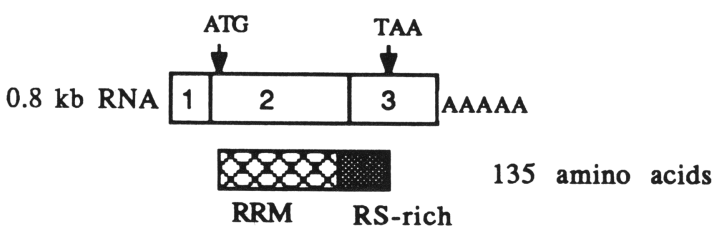

2. Type B.

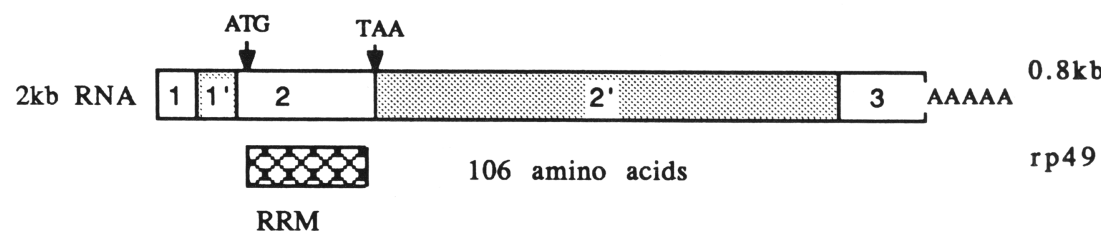

b Northern

Dorthern

$2.0 \mathrm{~kb}$

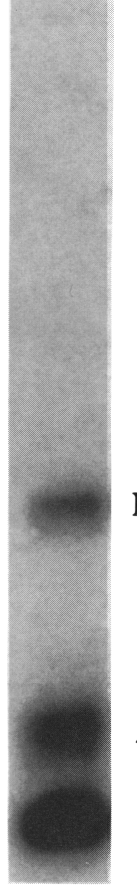

c

\section{Western}

B

A
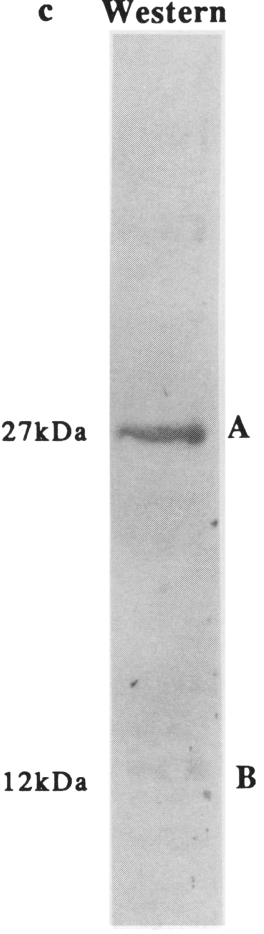

Figure 2. The organization of the $r b p 1$ gene, the transcripts, and the proteins it encodes. $(a \mid$ The structure of the $r b p 1$ gene, along with the initiation and stop codons and poly(A) signal, is shown. Two types of RNAs are shown. The exons used in type-A RNA are shown as open boxes, and the two introns that were retained in type-B RNA are shown as shaded boxes. The predicted protein structure of each type of RNA is shown under the RNAs, and the RRM and RS domains are indicated. (b) Two micrograms of Drosbphila embryonic poly $(\mathrm{A})^{+}$RNA was hybridized with the rbp1-a cDNA probe, which has only the three exon sequences used in the type-A RNA. Type-B RNA has two extra intron sequences, in addition to the three-exon sequence of type-A RNA. The Northern blot was also hybridized with an $\mathrm{rp} 49$ probe to show the relative abundance of the $r b p 1$ transcripts. (c) One microgram of adult fly nuclear proteins was used for Western analysis with anti-RBPl antibodies.

Western analysis of the bacterially produced $\mathrm{RBPl}$ protein and fusion proteins using anti-RBPI polyclonal antibodies showed that the antibodies recognized the bacterial RBP1 protein specifically with a very low background reactivity to Escherichia coli proteins (data not shown). In Western analysis of Drosophila nuclear extracts, the anti-RBP1 antibodies detected one strong band at the $27-\mathrm{kD}$ region and one very weak band at the 12-kD region (Fig. 2c). The predicted molecular mass of the protein from the type-A transcript is $15 \mathrm{kD}$ and, thus, is $12 \mathrm{kD}$ smaller than the molecular mass of the major peptide detected in the Western analysis. Analogous disparities between observed and predicted molecular mass are seen with other RRM-type RNA-binding proteins with an RS domain (ASF/SF2, Krainer et al. 1991; SRp55, Mayeda et al. 1992; U1-70K, Mancebo et al. 1990). The abnormal electrophoretic mobility of these proteins may be caused by the high number of charged amino acids in the RS domain and/or by a high level of phosphorylation of the protein.

Although the two types of $r b p 1$ transcripts were present in relatively equal amounts, only the $27-\mathrm{kD}$ polypeptide reacted strongly with the anti-RBP1 antibodies; the $12-\mathrm{kD}$ polypeptide presumably encoded by
type-B mRNA was barely detectable. Therefore, the efficiency of translation of type-B RNA is low, the type-B protein is rapidly degraded, or the polyclonal antibodies recognized principally the RS domain.

\section{Localization of the RBP1 protein}

To determine the tissue localization pattern of RBP1 protein, serial sections of adult flies were stained with antiRBPl antibodies, and the antibody-protein complex was visualized with a fluorescein-conjugated secondary antibody. The RBP1 protein appeared to be expressed in all tissues and localized in nuclei. The level of anti-RBP1 staining was not uniform across individual nuclei, and in all tissues examined the intensity of RBP1 staining paralleled the variations seen within that nucleus to the level of staining by bis-benzimide (Hoechst no. 33258), a dye that specifically stains chromatin (Fig. 5). This suggested that the RBPl protein may associate with chromosomes.

To examine whether RBPl was associated with chromosomes, we examined larval salivary gland polytene chromosomes using an indirect immunofluorescence assay (Silver and Elgin 1978). When chromosomes were 
a

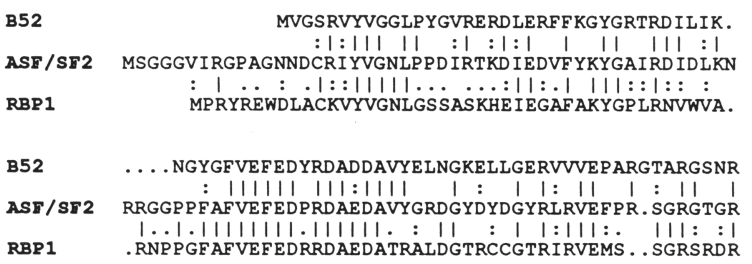

RBP1

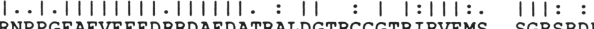

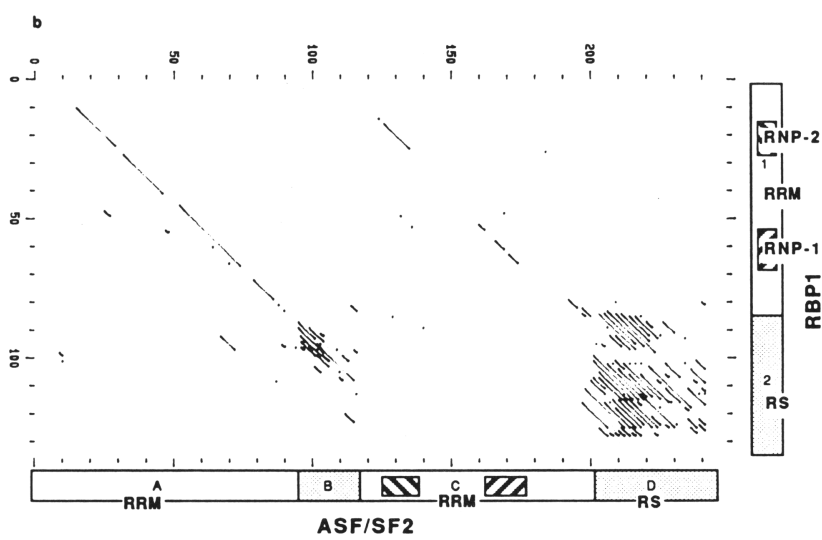

Figure 3. Sequence similarity of RBP1 to ASF/SF2. (a) The amino acid sequences of the RRMs of RBPl and ASF/SF2 are aligned using the BESTFIT program. Identical matches are shown with vertical bars, and functionally related matches are marked with single or double dots. Gaps in the alignment are shown by periods. (b) The amino acid sequences of RBPl and ASF/SF2 were compared and plotted using COMPARE and DOTPLOT programs. The regions of significant matches are indicated with diagonal lines. Protein domain structures are drawn along the axis of the matrix and are marked every 10 amino acids.

stained with anti-RBP1 antibodies, a number of bands, $\sim 50$ per chromosome arm, were brightly stained, and $\sim 10 \%$ of these staining sites (particularly the puffs at $2 \mathrm{~B}$, 23C, 43E, 47C, 56D, 68C, 71DE, 73D, 74E, and 991 showed a very high accumulation of RBP1 protein (Fig. 6a). In addition to preferential localization to these puffs, a low level of general staining was seen near the centromere. When we used preimmune serum or anti-RBP1 antibodies that were depleted by incubating with a large amount of RBP1 protein, the intensity of the RBPl antibody staining signal was greatly diminished and only a low level of general background staining was detected from chromosomes and background tissues (data not shown). This suggests that the staining pattern shown in Figure 6a reflects the distribution of the RBP1 protein.

Among the anti-RBPl antibody-stained bands, the most intense are observed at the cytologically visible puffs, which are transcriptionally active sites on polytene chromosomes (Pelling 1964; Alcover et al. 1982). To inquire whether RBP1 protein localization and active transcription were related, we compared the distribution of the RBPl protein and RNA polymerase II on polytene chromosomes. Chromosomes were incubated with rabbit anti-RBPl antibodies and goat anti-RNA polymerase
II antibodies together, and the RBPI antibody complex and the RNA polymerase antibody complex were visualized as described in Materials and methods. The results (Fig. 6) show that the localization pattern of RNA polymerase II appears to be the same as the RBP1 localization pattern: When the staining patterns of cells doubly stained with anti-RBP1 and anti-RNA polymerase antibodies are superimposed, an identical staining pattern of $\mathrm{RBPl}$ and RNA polymerase II is observed.

\section{Functional assay of recombinant RBP1 protein}

The sequence similarity between RBP1 and ASF/SF2 prompted us to test whether RBP1 can functionally substitute for ASF/SF2 in the assays that have been used to characterize ASF/SF2 function. ASF/SF2 can influence splicing in vitro in at least two ways /Ge and Manley 1990; Ge et al. 1991; Krainer et al. 1990; 1991; Harper and Manley 1992). First, ASF/SF2 can act as an essential splicing factor by activating splicing, when added to an otherwise inactive HeLa cell S-100 extract. Second, it can act as an alternative splicing factor, by influencing $5^{\prime}$ splice site selection in a concentration-dependent manner. To test whether RBPl possessed either or both of these activities, ASF-1 (Ge et al. 1991) and RBP1 proteins were expressed in $E$. coli and purified as described in Materials and methods. Figure 7 shows the effects of both proteins on the splicing of an SV40 early premRNA. As shown previously for ASF-1 (Ge et al. 1991), both proteins were able to switch $5^{\prime}$ splice site selection from the distal large $\mathrm{T} 5^{\prime}$ splice site to the proximal small t $5^{\prime}$ splice site in a concentration-dependent manner (Fig. 7a). As the proteins were prepared in identical ways and equivalent molar amounts of each were used, we conclude that RBPl can function to switch SV40 5' splice site selection in vitro in a manner indistinguishable from that of ASF-1. In contrast, when tested for its

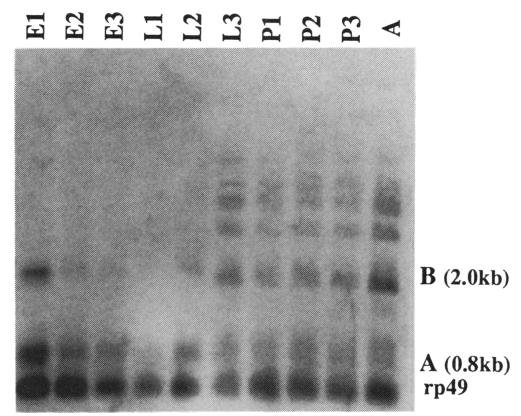

Figure 4. Developmental Northern blot of $r b p 1$. Two micrograms of poly(A) ${ }^{+}$RNA from each developmental stage was electrophoresed, transferred to nitrocellulose, and probed with a ${ }^{32}$ P-labeled rbp1 cDNA. The blot was also hybridized with an rp49 cDNA probe as a control on the amount of RNA loaded in each lane. (Lane 1) 0 to 3-hr-old embryo; (lane 2) 3 to 12-hr-old embryo; (lane 3) 12 to 24 -hr-old embryo; (lane 4) first-instar larva; (lane 5) second-instar larva; (lane 6) third-instar larva; (lane 7) 1-day-old pupa; (lane 8) 2-day-old pupa; (lane 9) 3-dayold pupa; (lane 10) adult. 
Kim et al.

a

Figure 5. Antibody staining of adult fly tissue sections. $(b)$ Serial sections of adult flies were incubated with anti-RBP1 polyclonal antibodies, and the RBP1 protein-antibody complex was visualized with a fluorescene-conjugated secondary antibody. $|a|$ Nuclei of the cells were also stained with bis-benzimide. The gut cells of a fly are shown.

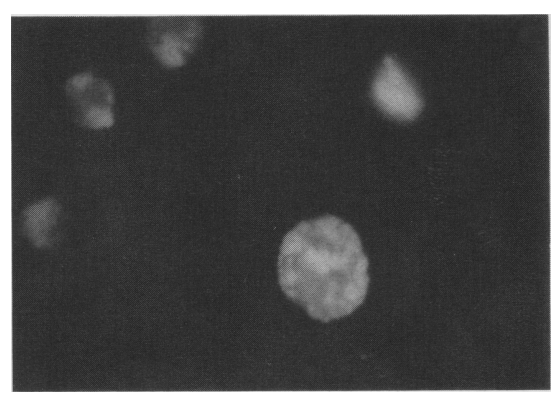

b

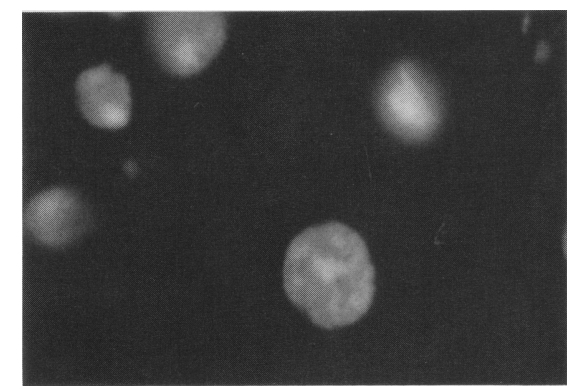

ability to activate SV40 splicing in an S-100 extract, RBP1 was completely inactive at all concentrations tested, indicating a clear difference in the functional properties of the two proteins (Fig. $7 \mathrm{~b}$; data not shown).

We also tested the ability of RBPl to affect the splicing of another well-characterized alternatively spliced premRNA, adenovirus Ela. This transcript is more complex than the SV40 pre-mRNA, containing three 5' splice sites that function with a shared $3^{\prime}$ splice site to generate 9S, 12S, and 13S mRNAs. The distal (9S) site can also function with a second, upstream $3^{\prime}$ splice site, which results in the synthesis of three additional species $112.5 \mathrm{~S}$, $10 S$, and 11S, the latter two being doubly spliced). All of these RNAs can be detected in vitro, and are subject to modulation by ASF-1 in a manner similar to that seen with SV40 pre-mRNA (Harper and Manley 1992). The effects of RBP1 on Ela splicing are shown in Figure 8. In contrast to the results obtained with SV40 pre-mRNA, addition of RBPl to an S-100 extract resulted in activation of splicing (Fig. 8A). However, RBPl was significantly less effective in activating Ela splicing than was ASF-1 at all concentrations tested (Fig. 8A; results not shown). As with ASF-1, 13S products, which reflect the use of the most proximal $5^{\prime}$ splice site, were detected almost exclusively in the S-100 extract.

RBPl could also influence splice site selection with the Ela pre-mRNA, but in a manner qualitatively distinct from ASF-1 (Fig. 8B). Whereas ASF-1 switches splice site selection such that $13 \mathrm{~S}$ splicing is strongly favored and use of all upstream splice sites is repressed (see also Harper and Manley 1992), the strongest effect of RBP1 was to block usage of the upstream 3' splice site. This prevents synthesis of the doubly spliced $10 \mathrm{~S}$ and $11 \mathrm{~S}$ RNAs (10S products are apparent on longer exposures; results not shown) and increases synthesis of $9 \mathrm{~S}$ and $12 \mathrm{~S}$, as well as 13S, RNAs. Although higher concentrations of ASF-1 can also inhibit 10 S and 11S splicing, increases in $9 S$ or $12 \mathrm{~S}$ splicing have never been observed (Fig. 8B; Harper and Manley 1992). The results obtained with the SV40 and adenovirus pre-mRNAs together indicate that RBPl can function as a splicing factor in a manner similar to ASF-1, but that there are qualitative and quantitative differences in the behavior of the two proteins. a

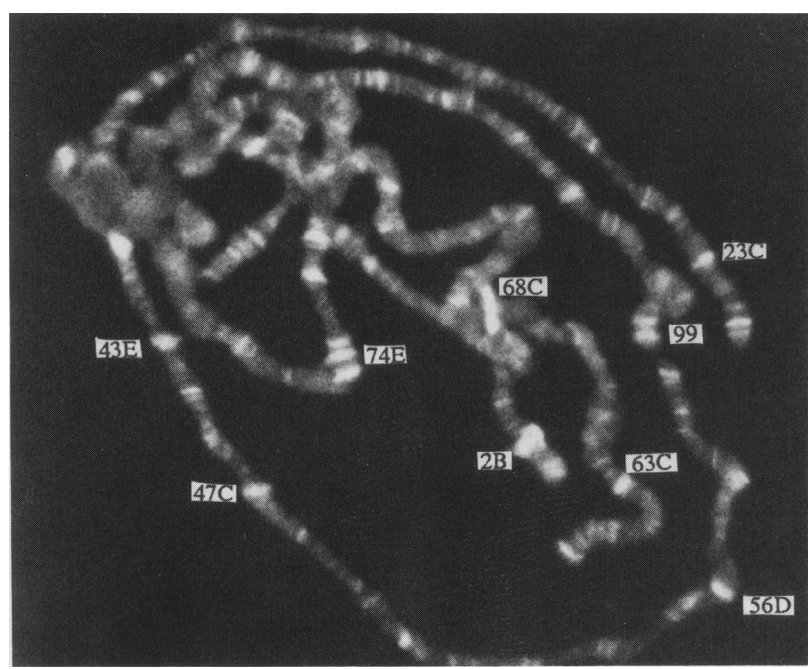

b

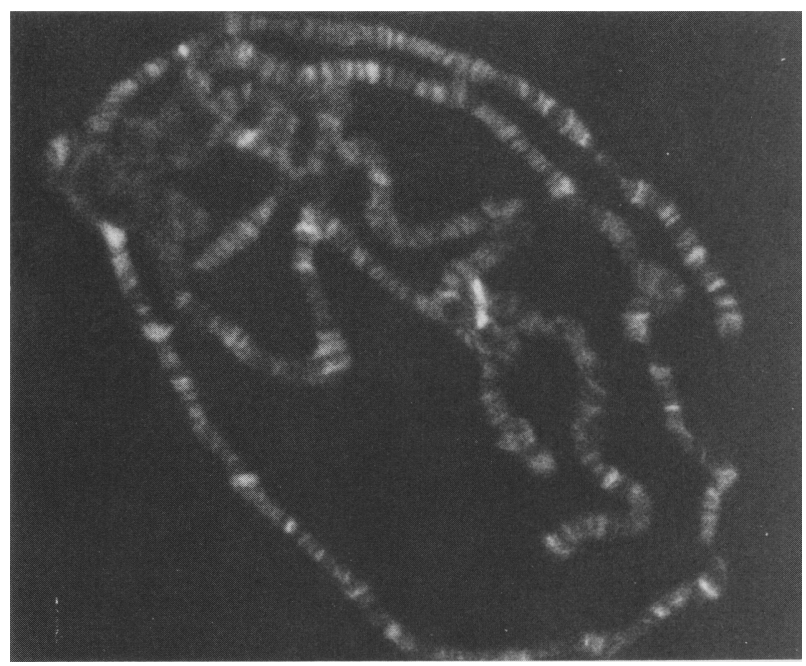

Figure 6. Distribution of RBP1 on polytene chromosomes. Indirect immunofluorescence of RBP1 $(a)$ and RNA polymerase II $(b)$ are shown. The cytological loci of the highly stained puffs are labeled. 


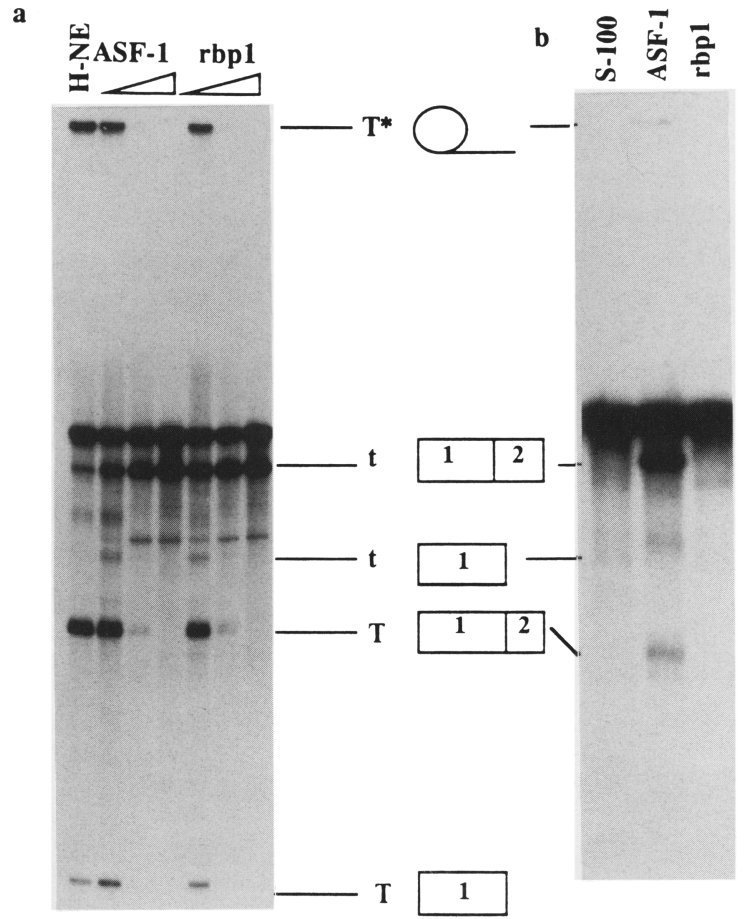

Figure 7. In vitro splicing assay of the RBPl protein using SV40 early pre-mRNA. $\left\{a \mid\right.$ In vitro splicing of a ${ }^{32} \mathrm{P}$-labeled pSVi66 pre-mRNA (Fu and Manley 1987) was performed in reaction mixtures containing HeLa nuclear extract alone (H-NE) or HeLa nuclear extract plus increasing amounts of ASF-1 or RBP1 proteins. The resulting products were analyzed on a $5 \%$ denaturing polyacrylamide gel. (Lane 1) HeLa nuclear extract alone; (lanes 2-4) HeLa nuclear extract plus $0.25,0.63$, and $1.25 \mu \mathrm{g}$ of ASF-1; (lanes 5-7) HeLa nuclear extract plus $0.25,0.63$, and $1.25 \mu \mathrm{g}$ of RBP1. The structures of products and intermediates are indicated schematically at right. $(b)$ In vitro splicing reactions were carried out as in $|a|$, except that $\mathrm{S}-100$ extract was substituted for nuclear extract. (Lane 1) S-100 extract alone; (lane 2) S-100 extract plus ASF-1 protein (1.25 $\mu \mathrm{g}$ ); (lane 3) S-100 extract plus $\mathrm{RBPl}$ protein $(0.9 \mu \mathrm{g})$. The structures of products and intermediates are indicated at left.

\section{Discussion}

The sequence similarity of RRM1 to the RRM of a human alternative splicing factor (ASF/SF2) led us to test whether this sequence similarity is really reflecting a functional similarity of the RBP1 and ASF/SF2 proteins. From our studies, we found three additional features that extend the similarity between $r b p 1$ and ASF/SF2. The first is that the sequence similarity extends to the entire RRM and RS domains of these proteins. Second, the RBP1 protein colocalizes with RNA polymerase II at transcriptionally active sites on larval salivary gland polytene chromosomes and is thus likely to play a general role in mRNA processing. Third, $\mathrm{RBPl}$ protein made in $E$. coli affects the in vitro splicing pattern of SV40 early and adenovirus Ela pre-mRNAs. We elaborate on each of these points below.

First, the amino acid sequence of $r b p 1$ revealed two striking structures: an RRM and an RS domain. The
RRMs are found in proteins involved in diverse aspects of RNA processing and have been shown to be responsible for RNA-binding activity in several cases. The RRM of RBP1 has $37-47 \%$ identity to the RRMs of B52, SRp55, and ASF/SF2, suggesting a close functional relation between these proteins.

In addition to the high similarity of the RRM to that of ASF/SF2, the presence of the RS domain at the carboxyterminal end of the protein extends the similarity between these proteins. An RS domain has been found in su $\left(w^{a}\right)$ (Chou et al. 1987), tra (Boggs et al. 1987), tra-2, ASF/SF2, U1-70K snRNP (Theissen et al. 1986), U2AF (Zamore et al. 1992), Drosophila nuclear phosphoprotein SRp55 (Mayeda et al. 1992), and Drosophila puff-associated gene B52 (Champlin et al. 1991). Although the function of RS domains is not yet known, the fact that all of the known proteins with an RS domain are involved in some aspects of RNA splicing is intriguing. In particular, the fact that ASF/SF2 appears to have two repeats of RRM and RS domains suggests that the single RRM and $\mathrm{RS}$ domain found in RBPl may be a basic unit structure involved in RNA metabolism.

The second piece of data that is consistent with a role of $r b p 1$ in RNA processing comes from the localization pattern of RBP1. The nuclear localization of RBP1 protein at transcriptionally active sites on chromosomes is very similar to the localization pattern of the Drosophila RRM protein B52 (Champlin et al. 1991). Three observations suggest that the protein localization result may indicate that these proteins have a role in RNA processing. First, the accumulation of transcription products (Pelling 1964; Alcover et al. 1982), RNA polymerase II

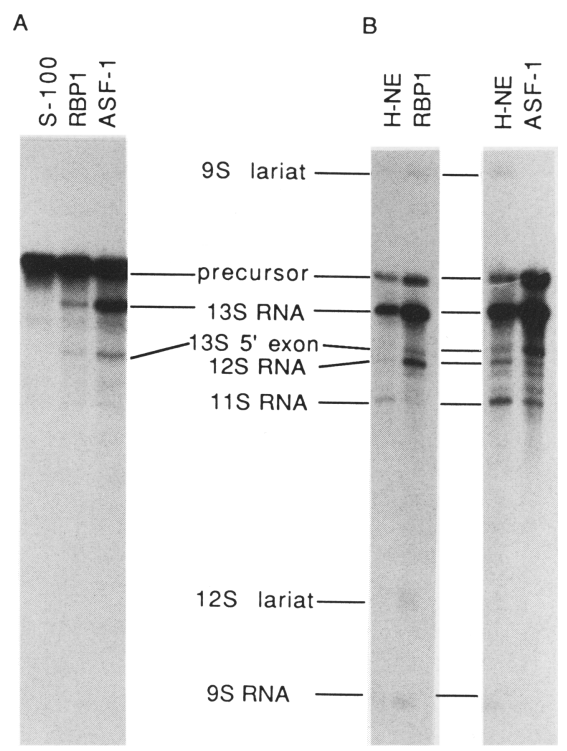

Figure 8. Effects of RBP1 and ASF-1 proteins on adenovirus Ela splicing in vitro. Splicing reactions were performed exactly as in Fig. 7, except that an adenovirus Ela pre-mRNA was used. Reaction mixtures contained either HeLa S-100 $(a)$ or nuclear $(b)$ extract plus $1.25 \mu \mathrm{g}$ of ASF-1 or $0.9 \mu \mathrm{g}$ of RBP1. Positions of major products and intermediates are indicated. 
(Bonner and Kerby 1982), and RNP particles (Skoglund et al. 1983) have been detected particularly on puffs of polytene chromosomes, and splicing has been shown to occur cotranscriptionally on Drosophila chromosomes (Osheim et al. 1985). These results suggest that not only are transcription and the modification of chromatin structure occurring at the puffed regions of chromosomes, but the processing of newly transcribed RNAs are occurring as well. Second, Mayeda et al. (1992) showed that a Drosophila nuclear phosphoprotein, SRp55, (a nearly identical variant of Drosophila B52) can replace the general as well as the regulatory activity of human ASF/SF2 in a human cell-free system. Finally, like SRp55, B52 shows significant sequence similarity to the human splicing factor ASF/SF2. Therefore, the localization pattern of RBP1 and B52 proteins with a similarity to the human splicing factor ASF/SF2 can be interpreted as suggesting a role for these proteins in RNA processing.

Further support for $r b p 1$ functioning in splicing comes from the in vitro splicing activity of RBPl protein. Our in vitro experiments using bacterially produced protein and human cell extracts showed that RBPl can influence the splicing patterns of two alternatively spliced pre-mRNAs. Although it remains to be determined what $r b p 1$ does in vivo, one possible interpretation of this result is that $r b p 1$ plays a role in pre-mRNA splicing. It is intriguing that RBPl can function in HeLa extracts as an alternative splicing factor, but only poorly as an essential factor. Although it is conceivable that this reflects a species-specific difference, we consider this unlikely. It has been shown that Drosophila SRp55 can fully complement both functions of ASF/SF2 (Mayeda et al. 1992), and we have recently obtained similar results with B52 (P. Zuo, J. Manley and J. Lis, unpubl.). Although further work is required to understand the basis for the functional differences between $r b p 1$ and ASF/SF2, one obvious possibility is that a region within regions $B$ and $C$ of ASF/SF2 and SRp55/B52, which is missing in RBP1, is required for their full function. Whatever the structural basis for the differences, the ability of these two related proteins to influence splicing in distinct ways may have important implications for regulation of splice site selection in vivo.

While this manuscript was in preparation, a paper appeared describing the existence of a conserved family of proteins with significant similarity to ASF/SF2 and RBP1 (Zahler et al. 1992). These proteins were found in organisms from Caenorhabditis elegans to humans, including Drosophila, and were characterized initially according to their apparent molecular masses, which are $\sim 20,30,40,55$, and $75 \mathrm{kD}$. The proteins all contain an RRM and RS repeat region, and, intriguingly, the four largest were all able to activate splicing in S-100 extracts. We suggest that RBP1 may be equivalent to the $20-\mathrm{kD}$ proteins of Zahler et al., and our results suggest further that the function of these smaller proteins is distinct from the larger ones; that is, the small proteins may modulate splice site selection in distinctive ways and may be less able to function as essential splicing factors.

The general expression pattern of $r b p 1$ in all tissue types throughout development does not seem to be suitable for an alternative splicing factor that usually regulates tissue- or stage-specific splicing. However, generally expressed factors can exercise their specific functions during development by interacting with other tissue- or stage-specific factors as was shown in the case of tra-2, which regulates sex-specific, as well as germline-specific, alternative splicing (Mattox and Baker 1991) but is expressed ubiquitously.

With respect to future studies of $r b p 1$, the isolation of $r b p 1$ mutants and target RNAs of RBPI protein using genetic as well as biochemical approaches will not only clarify the function of $r b p 1$ but may also provide insights into the mechanisms that control cell type-specific RNA-processing decisions.

\section{Materials and methods}

\section{Library screen}

Recombinant phage $\left(2 \times 10^{5}\right)$ were screened from each of the following libraries: a $\lambda$ gt 10 adult fly cDNA library (provided by L. Kauvar, University of California, San Franciscol, and a $\lambda_{n v x}$ third-instar larva cDNA library (provided by S. Elledge, Baylor College of Medicine, Houston, Texas). We also screened $1 \times 10^{4}$ colonies from a Drosophila cosmid library (provided by J.W. Tamkun, National Institute of Health, Bethesda, Maryland), and $2 \times 10^{5}$ recombinant phage from a Charon-4 Drosophila genomic library (Maniatis et al. 1978). All of the procedures for the isolation of positive clones followed conventional protocols (Sambrook et al. 1989).

\section{Sequencing and computer analysis}

The cDNA fragments from five positive cDNA clones were subcloned into a pBluescript vector, and unidirectional deletions were introduced into the cloned fragments using exonuclease III and nuclease SI (Henikoff 1984). Single-stranded templates were prepared by standard methods and sequenced by the method of Sanger et al. (1977). The rbp1 gene was localized to a $2.7-\mathrm{kb}$ SacI-ApaLI genomic fragment by Southern hybridizations. This fragment was subcloned, and serial deletions and sequencing were done as for the cDNAs.

Computer programs used for sequence analysis were from the University of Wisconsin GCG package (Devereux et al. 1984). The GenBank (release 62.0) and EMBL (release 22.0) nucleotide sequence data bases were scanned with the program TFASTA for the homologous proteins. ASF/SF2 and RBP1 sequence comparison was done using the programs COMPARE and DOTPLOT at three different conditions (window 15, stringency 9; window 20, stringency 12; window 30, stringency 15). These conditions gave almost identical results. The structural analysis of ASF/SF2 and RBP1 sequences was done using the programs PEPTIDESTRUCTURE (Chow-Fasman prediction) and PLOTSTRUCTURE.

\section{Developmental Northern analysis}

For developmental Northern analysis, $2 \mu \mathrm{g}$ of poly(A) ${ }^{+}$RNA from the each developmental stage was separated on a $1 \%$ agarose-formaldehyde gel and transfered to Nytran. The filters were hybridized with typeA rbp1 cDNAs. Hybridizations were done using the condition described by Nagoshi and Baker (1990). 
Production of polyclonal antibodies to lacZ-RBP1 fusion protein and $p R B P 1$ protein

We expressed RBPl protein in two expression systems: the lacZ fusion system (Guo et al. 1984), to immunize rabbits with a RBP1 protein containing a large carrier molecule; and the T7 polymerase bacterial expression system (Rosenberg et al. 1987) to use the expressed protein for an immunogen for the later boosts as well as for in vitro splicing experiments. The $0.7-\mathrm{kb}$ fragment from the $r b p 1-a$ cDNA, which contains the entire coding sequence plus 53 nucleotides of $3^{\prime}$-flanking sequence lacking the termination signal, was subcloned into plasmid pWR590-a (Guo et al. 1984) to make pZRBP1, which contained a truncated $E$. coli $\beta$-galactosidase-coding region fused in-frame to $r b p 1$. To clone only the coding sequence of $r b p 1$ from the initiation codon ATG, the rbp1-a cDNA was amplified via PCR using the universal primer (5'-GTAAAACGACGGCCAGT-3') and rbplATG-Nde primer $\left(5^{\prime}\right.$-ATCATATGCCGCGATATAGGGA-3'), which is homologous to the sequence $3^{\prime}$ to the first AUG of the ORF. The PCR-amplified fragment was digested with NdeI and BamHI and ligated into NdeI- plus BamHI-cut pET3a plasmid (Rosenberg et al. 1987) to make pRBP1. One liter of dYT broth containing $100 \mu \mathrm{g} / \mathrm{ml}$ of carbanecillin was inoculated with JM101-pZRBP1, or BL21-lysS-pRBP1, and the culture was induced with IPTG (final concentration, $0.5 \mathrm{~mm}$ ) at the late $\log$ phase. After 2 more hours of cultivation at $37^{\circ} \mathrm{C}$, cells were harvested and frozen at $-80^{\circ} \mathrm{C}$ until ready for use. The cells were resuspended in $50 \mathrm{mM}$ Tris- $\mathrm{HCl}(\mathrm{pH} 7.5), 250 \mathrm{mM}$ $\mathrm{NaCl}$, and lysed with lysozyme and Triton-X100. After sonication, the lysate was centrifuged at $10,000 \mathrm{~g}$ for $30 \mathrm{~min}$ through a $20 \%$ sucrose cushion to precipitate inclusion bodies. The pellet was resuspended in solubilization buffer $18 \mathrm{M}$ urea, $50 \mathrm{~mm}$ Tris$\mathrm{HCl}$ at $\mathrm{pH} 7.5,250 \mathrm{mM} \mathrm{NaCl}$, and the salts were removed by dialysis. After the dialysis, soluble fraction was separated on an $4 \%$ stacking $/ 8 \%$ polyacrylamide-SDS gel. The lacZ-RBP1 fusion protein or $E$. coli RBP1 protein band was eluted from the gel, dialyzed against distilled water, and lyophilized. About 200 $\mu \mathrm{g}$ of the lacZ-RBPl fusion protein was added to a vial of MPL + TDM + CWS adjuvant (RIBI Immunochem) and injected into two New Zealand white rabbits according to the manufacturer's instructions. For the first four injections, lacZRBPl fusion protein was given to the rabbits every 4 weeks. Subsequently, $200 \mu \mathrm{g}$ of $E$. coli RBP1 protein from pRBP1 was injected six more times at 4 -week intervals.

\section{Affinity purification of anti-RBP1 antibodies}

The purified pRBPl protein was coupled to Affigel-10 (Bio-Rad) at a concentration of $2 \mathrm{mg} / \mathrm{ml}$ of resin according to procedures recommended by the manufacturer. After coupling, blocking, and washing, the resins were mixed overnight with $200 \mathrm{ml}$ of 10 -fold diluted serum from immunized rabbits. The next morning, after extensive washing, bound antibodies were eluted with 2 or $3 \mathrm{ml}$ of $0.1 \mathrm{M}$ glycine $(\mathrm{pH} 2.8)$, neutralized immediately with $30 \mu \mathrm{l}$ of $1 \mathrm{~m}$ Tris- $\mathrm{HCl}(\mathrm{pH} 9.0)$ and stored with $0.02 \%$ sodium azide and $1 \%$ BSA.

\section{Western analysis}

Crude nuclear extracts from adult flies were prepared as described in Kuroda et al. (1991). Electrophoresis of nuclear extracts, transfer of proteins to nitrocellulose, and immunostaining of the blots were performed as described in Harlow and Lane (1988).

\section{Immunostaining of fly sections}

To make sections for immunostaining, adult y $w$ flies were embeded in O.C.T. compound and frozen with liquid $\mathrm{CO}_{2}$. Eight-micron sections of frozen flies were cut on a SLEE cryostat, and the serial sections were mounted on subbed slides. Sections were fixed in PBS containing $4 \%$ paraformaldehyde for 30 min. After blocking with $5 \%$ goat serum in TFN $150 \mathrm{~mm}$ Tris- $\mathrm{HCl}$ at $(\mathrm{pH} 8), 150 \mathrm{mM} \mathrm{NaCl}, 0.5 \% \mathrm{NP}-40$ ), the sections were incubated with affinity-purified RBP1 antibodies at a dilution of $1: 100$. Fluorescein-conjugated anti-rabbit IgG goat antibody (Cappel) at a $1: 100$ dilution and $1 \mu \mathrm{g} / \mathrm{ml}$ of bis-benzimide were used to visualize the RBPl protein-antibody complex and DNA, respectively. Slides were mounted in $80 \%$ glycerol, and $2 \% \mathrm{~N}$-propyl gallate. The sections were viewed under epifluorescence optics using a Zeiss Axiophot microscope and photographed with Kodak Ektachrome P800/P1600 film.

\section{Indirect immunofluorescence of polytene chromosomes}

Polytene chromosomes were prepared from Canton-S third-instar larvae as described (Zink and Paro 1989; Kuroda et al. 1991), with the following modifications. Salivary glands were dissected from third-instar larvae in $1 \times$ PBS, $0.1 \%$ Triton X-100, and fixed in $1 \times$ PBS, $1 \%$ Triton X-100, and $3.7 \%$ paraformaldehyde for $30 \mathrm{sec}$. The glands were transferred to $0.5 \times$ PBS, $50 \%$ acetic acid, and $3.7 \%$ paraformaldehyde for $2 \mathrm{~min}$, transferred to $25 \mu \mathrm{l}$ of acetic acid/lactic acid/water $(3: 2: 1)$ on a siliconized coverslip, and then squashed. Immunostaining was done as described (Pirrotta et al. 1988) with the following modifications. A 1 : 50 dilution of rabbit anti-RBP1 antibodies and $1: 100$ dilution of goat anti-RNA polymerase II antibodies (gift from A. Greenleaf, Duke University, Durham, North Carolina) were incubated together as primary antibodies. Rhodaminin-conjugated sheep anti-rabbit IgG and fluorescein-conjugated swine anti-goat IgG secondary antibodies were used at a $1: 100$ dilution. The chromosomes were viewed under epifluorescence optics using a Zeiss Axiophot microscope and photographed with Kodak Ektachrome P800/P1600 film.

\section{In situ hybridization to polytene chromosome}

Salivary gland polytene chromosomes from third-instar larvae of the Canton-S wild-type strain were prepared and hybridized as described by Zuker et al. (1985). The rbp1 cDNA fragment was labeled by nick translation using bio-16dUTP (ENZO Biochem). Signal was detected with streptavidin-conjugated horseradish peroxidase (ENZO Biochem) and diaminobenzidine.

The cytological location of $r b p 1$ was determined to be at $86 \mathrm{D}$ of larval salivary gland polytene chromosomes by in situ hybridization with the $r b p 1-a$ cDNA probe.

\section{Expression and purification of cloned RBP1 in E. coli}

pET-RBPl and pDSASF-1H (Ge et al. 1991) were transformed into the bacterial strains BL21 and JM101, respectively, and induced with $1 \mathrm{mM}$ IPTG when the $\mathrm{OD}_{600}$ reached $\sim 0.5$. Bacterial pellets harvested from 200 -ml cultures were directly resuspended in $3 \mathrm{ml}$ of $1 \times$ Laemmli protein gel loading buffer. The samples were boiled for $5 \mathrm{~min}$, and recombinant proteins were purified by preparative SDS-PAGE. The acetone-precipitated protein pellets were resuspended in $0.4 \mathrm{ml}$ of $6 \mathrm{M}$ guanidine- $\mathrm{HCl}(\mathrm{pH} 7.9)$ and mixed well on a Nutator for $1 \mathrm{hr}$ at $4^{\circ} \mathrm{C}$. The proteins were dialyzed first against $2 \mathrm{M}$ and then against 0.5 
M guanidine- $\mathrm{HCl}$ in buffer D $20 \mathrm{mM}$ HEPES at $\mathrm{pH} 7.9,20 \%$ glycerol, $42 \mathrm{mM}\left(\mathrm{NH}_{4}\right)_{2} \mathrm{SO}_{4}, 0.2 \mathrm{~mm}$ EDTA, and $0.5 \mathrm{~mm}$ DTT) for $2 \mathrm{hr}$ each. The final concentration of each protein, determined by Bradford assays, was $\sim 5 \mathrm{mg} / \mathrm{ml}$. Both RBPl and ASF-1 were also produced as histidine fusion proteins and purified by $\mathrm{Ni}^{2+}$ chelate chromatography (e.g., Ge et al. 1991). The activities in splicing assays of the proteins prepared by this method were identical to the activities obtained with SDS-gel-purified proteins.

\section{In vitro splicing assays}

Nuclear and cytoplasmic S-100 extracts were prepared from HeLa cells according to standard procedures (Dignam et al. $1983)$, except that $42 \mathrm{mM}\left(\left.\mathrm{NH}_{4}\right|_{2} \mathrm{SO}_{4}\right.$ was substituted for $0.1 \mathrm{M}$ $\mathrm{KCl}$ in buffer D (Noble et al. 1987). SV40 early (Ge et al. 1991) and adenovirus Ela (Harper and Manley 1991) pre-mRNAs were prepared by in vitro transcription as described. In vitro splicing reactions, both in nuclear and S-100 extracts, were carried out essentially as described (Ge et al. 1991). ASF-1H and pRBP1 proteins in $0.5 \mathrm{M}$ guanidine were diluted 20 -fold with buffer D immediately before splicing reactions, and $0,1,2.4$, or $5 \mu \mathrm{l}$ of diluted protein was added into each $25-\mu$ l reaction mixture. Concentrations of buffer D and guanidine $\mathrm{HCl}(5 \mathrm{~mm})$ were adjusted to be identical in all samples.

\section{Acknowledgments}

We thank A. Greenleaf for the generous gift of anti-RNA polymerase II antibodies. We also thank Wendy Wall, Lisa Ryner, and Claudia Zraly for comments on the manuscript, and Gennet Bohm for preparing media and laboratory supplies. We are most grateful to Joan Harper for help with the in vitro splicing experiments. This work was supported by grants from the National Institutes of Health.

The publication costs of this article were defrayed in part by payment of page charges. This article must therefore be hereby marked "advertisement" in accordance with 18 USC section 1734 solely to indicate this fact.

\section{References}

Alcover, A., M. Izqueirdo, D. Stollar, Y. Kitagawa, M. Miranda, and C. Alonso. 1982. In situ immunofluorescent visualization of chromosomal transcripts in polytene chromosomes. Chromosoma 87: 263-277.

Amrein, H., M. Gorman, and R. Nothiger. 1988. The sex-determining gene tra-2 of Drosophila encodes a putative RNA. binding protein. Cell 55: 1025-1035.

Bandziulis, R.J., M.S. Swanson, and G. Dreyfuss. 1989. RNAbinding proteins as developmental regulators. Genes \& Dev. 3: $431-437$.

Bell, L. R., E. M. Maine, P. Schedl, and T. W. Cline. 1988. Sexlethal, a Drosophilasex determination switch gene, exhibits sex-specific RNA splicing and sequence similarity to RNAbinding proteins. Cell 55: 1037-1046.

Bentley, R.C. and J.D. Keene. 1991. Recognition of U1 and U2 small nuclear RNAs can be altered by a 5-amino-acid segment in the U2 small nuclear ribonuclearprotein particle $B^{\prime \prime}$ and through inter-actions with U2 snRNP A' protein. Mol. Cell. Biol. 11: 1829-1839.

Boggs, R.T., P. Gregor, S. Idriss, I.M. Belote, and M. McKeown. 1987. Regulation of sexual differentiation in Drosophila melanogaster via alternative processing of RNA from the transformer gene. Cell 50: 739-747.
Bonner, J.J. and R.L. Kerby. 1982. RNA polymerase II transcribes all of the heat shock induced genes of Drosophila melanogaster. Chromosoma 85: 93-108.

Burd, C.G., M.S. Swanson, M. Gorlach, and G. Dreyfuss. 1989. Primary structures of the heterogeneous nuclear ribonucleoprotein $\mathrm{A} 2, \mathrm{~B} 1$ and $\mathrm{C} 2$ proteins: A diversity of RNA binding proteins is generated by small peptide inserts. Proc. NatI. Acad. Sci. 86: 9788-9792.

Chambers, J.C. and J.D. Keene. 1985. Isolation and analysis of cDNA clones expressing human lupus $L a$ antigen. Proc. Natl. Acad. Sci. 82: 2115-2119.

Chambers, J.C., D. Kenan, B.J. Martin, and J.D. Keene. 1988. Genomic structure and amino acid sequence domains of the human La autoantigen. I. Biol. Chem. 263: 108043-108051.

Champlin, D.T., M. Frasch, H. Saumweber, and J.T. Lis. 1991. Characterization of a Drosophila protein associated with boundaries of transcriptionally active chromatin. Genes \& Dev. 5: 1611-1621.

Chou, T.-B., Z. Zachar, and P.M. Bingham. 1987. Developmental expression of a regulatory gene is programmed at the level of splicing. EMBO 1. 6: 4095-4104.

Deutscher, S.L., J.B. Harley, and J.D. Keene. 1988. Molecular analysis of the $60 \mathrm{kDa}$ human Ro ribonucleoprotein. Proc. Natl. Acad. Sci. 85: 9479-9483.

Devereux, J., P. Haeberli, and O. Smithies. 1984. A comprehensive set of sequence analysis programs for the VAX. Nucleic Acid. Res. 12: 387-395.

Dignam, J.D., R.M. Lebovitz, and R.G. Roeder. 1983. Accurate transcription initiation by RNA polymerase II in a soluble extract from isolated nuclei. Nucleic Acids Res. 11: 14751489.

Dreyfuss, G., M.S. Swanson, and S. Piñol-Roma. 1988. Heterogeneous nuclear ribonucleoprotein particles and the pathway of mRNA formation. Trends Biochem. Sci. 13: 86-91.

Fu, X.Y. and J.L. Manley. 1987. Factors influencing alternative splice site utilization in vivo. Mol. Cell. Biol. 7: 738-748.

Ge, H. and J.L. Manley. 1990. A protein factor, ASF, controls cell-specific altemative splicing of SV40 early pre-mRNA in vitro. Cell 62: 25-34.

Ge, H., P. Zuo, and J.L. Manley. 1991. Primary structure of the human splicing factor ASF reveals similarities with Drosophila regulators. Cell 66: 373-382.

Goralski, T.I., J.-E. Edstrom, and B.S. Baker. 1989. The sex determination locus transformer-2 of Drosophila encodes a polypeptide with similarity to RNA-binding proteins. Cell 56: 1011-1018.

Guo, L.-H., P.P. Stepien, J.Y. Tso, R. Brousseau, S. Narang, D.Y. Thomas, and R. Wu. 1984. Synthesis of human insulin gene. VIII. Construction of expression vectors for fused proinsulin production in Escherichia coli. Gene 29: 251-254.

Habets, W.J., M.H. Hoet, P. Bringmann, R. Luhrmann, and W. van Venrooij. 1985. Autoantibodies to ribonucleoprotein particles containing $\mathrm{U} 2$ small nuclear RNA. EMBO $I$. 4: 1545-1550.

Harlow, E. and D. Lane. 1988. Antibodies; A laboratory manual. Cold Spring Harbor Laboratory, Cold Spring Harbor, New York.

Harper, J.E. and J.L. Manley. 1991. A novel protein factor is required for use of distal alternative 5' splice sites in vitro. Mol. Cell. Biol. 11: 5945-5953.

_- 1992. Multiple activities of the human splicing factor ASF. Gene Expression 2: 19-29.

Henikoff, S. 1984. Unidirectional digesting with exonuclease III creates targeted breakpoints for DNA sequencing. Gene 28: $351-359$.

Kenan, D.J., C.C. Query, and J.D. Keene. 1991. RNA recogni- 
tion: Towards indentifying determinats of specificity. Trends Biochem. Sci. 16: 214-220.

Kim, Y.-J. and B.S. Baker. 1993. Isolation of RRM-type RNAbinding protein genes and the analysis of their relatedness using a numberical approach. Mol. Cell Biol. (in press).

Krainer, A.R., G. Conway, and D. Kozak. 1990. The essential pre-mRNA splicing factor SF2 influences 5' splice site selection by activating proximal sites. Cell 62: 35-42.

Krainer, A.R., A. Mayeda, D Kozak, and G. Binns. 1991. Functional expression of cloned human splicing factor SF2: Homology to RNA-binding proteins, U1 $70 \mathrm{k}$, and Drosophila splicing regulators. Cell 66: 383-394.

Krisch, H.M. and B. Allet. 1982. Nucleotide sequences involved in bacteriophage T4 gene 32 translational self-regulation. Proc. Natl. Acad. Sci. 79: 4937-4941.

Kuroda, M.I., M.J. Kernan, R. Kreber, B. Ganetzky, and B.S. Baker. 1991. The maleless protein associates with the $\mathrm{X}$ chromosome to regulate dosage compensation in Drosophila. Cell 66: 935-947

Mancebo R., P.C. Lo, and S.M. Mount. 1990. Structure and expression of the Drosophila melanogaster gene for the U1 small nuclear ribonucleoprotein particle $70 \mathrm{k}$ protein. Mol. Cell. Biol. 10: 2492-2502.

Maniatis, T., R.C. Hardison, E. Lacy, J. Lauer, C. O'Connell, D. Quon, G.K. Sim, and A. Estratiadis. 1978. The isolation of structural genes from libraries of eukaryotic DNA. Cell 15: 687-701.

Mattaj, I.W. 1989. A binding consensus: RNA-protein interactions in splicing, snRNPs, and sex. Cell 57: 1-3.

Mattox, W. and B.S. Baker. 1991. Autoregulation of the splicing of transcripts from the transformer-2 gene of Drosophila. Genes \& Dev. 5: 786-796.

Mayeda, A., A.M. Zahler, A.R. Krainer, and M.B. Roth. 1992. Two members of a conserved family of nuclear phosphoproteins are involved in pre-mNRA splicing. Proc. Natl. Acad. Sci. 89: 1301-1304.

Milburn, S.C., J.W. Hershey, M.V. Davies, K. Kelleher, and R.J. Kaufman. 1990. Cloning and expression of eukaryotic initiation factor $4 \mathrm{~B}$; sequence determination identifies a common RNA recognition motif. EMBO I. 9: 2783-2790.

Nagoshi, R.N. and B.S. Baker. 1990. Regulation of sex-specific RNA splicing of the Drosophila doublesex gene: Cis-acting mutations in exon sequences alter sex-specific RNA splicing patterns. Genes \& Dev. 4: 89-97.

Noble, J.C.S., Z.-Q. Pan, C. Prives, and J.L. Manley. 1987. Splicing of SV40 early pre-mRNA to large $T$ and small $t$ mRNAs utilizes different patterns of lariat branch sites. Cell 50: 227236.

Osheim, Y.N., O.L. Miller Jr., and A.L. Beyer. 1985. RNP particles at splice junction sequences on Drosophila chorion transcripts. Cell 43: 143-151.

Pelling, C. 1964. Ribonukleinsaure-synthese der reisenchromosomen. Autoradiographische untersuchungen an Chironomus tentans. Chromosoma 15: 71-122.

Pinkham, J.L. and T. Platt. 1983. The nucleotide sequence of the rho gene of E. coli K-12. Nucleic Acids Res. 11: 3531-3545.

Pirrotta, V., S. Bickel, and C. Marinai. 1988. Developmental expression of the Drosophila zeste gene and localization of zeste protein on polytene chromosomes. Genes \& Dev. 2: 1839-1850.

Query, C.C., R.C. Bentley, and J.D. Keene. 1989. A common RNA recognition motif identified within a defined Ul RNA binding domain of the 70k U1 snRNP protein. Cell 57: 89101.

Raabe, T., F. Bollum, and J.L. Manley. 1991. Primary structure and expression of bovine poly|A) polymerase. Nature
353: 229-234.

Rosenberg, A.H., B.N. Lade, D. Chui, S. Lin, J.J. Dunn and F.W. Studier. 1987. Vectors for selective expression of cloned DNAs by T7 RNA polymerase. Gene 85: 6642-6646.

Sachs, A.B., M.W. Bond, and R.D. Kornberg. 1986. A single gene from yeast for both nuclear and cytoplasmic polyadenylatebinding proteins: Domain structure and expression. Cell 45: $827-835$.

Sachs, A.B., R.W. Davis, and R.D. Kornberg. 1987. A single domain of yeast poly(A)-binding protein is necessary and sufficient for RNA binding and cell viability. Mol Cell. Biol. 7: 3268-3276.

Sambrook, J., E.F. Fritsch, and T. Maniatis. 1989. Molecular cloning; A laboratory manual, 2 ed. Cold Spring Harbor Laboratory Press, Cold Spring Harbor, New York.

Sanger, F., S. Nicklen, and A.R. Coulson. 1977. DNA sequencing with chain-terminating inhibitors. Proc. Natl. Acad. Sci. 74: 5463-5467.

Scherly, D., W. Boelens, N.A. Dathan, W.J. van Venrooij, and I.W. Mattaj. 1990. Major determinants of the specificity of interaction between small nuclear ribonucleoproteins UlA and U2B" and their cognate RNAs. Nature 345: 502-506.

Shannon, K.W. and C. Guthrie. 1991. Suppressors of a U4 snRNA mutation define a novel U6 snRNP protein with RNAbinding motifs. Genes \& Dev. 5: 773-785.

Sillekens, P.T.G., R.P. Beijer, W.J. Habets, and W.J. van Venrooij. 1988. Human Ul snRNP-specific C protein: Complete cDNA and protein sequence and identification of a multigene family in mammals. Nucleic Acids Res. 16: 8037-8321.

Silver, L.M. and S.C.R. Elgin. 1978. Immunological analysis of protein distributions in Drosophila polytene chromosomes. In The cell nucleus (ed. J.Busch) Vol. 5, pp. 215-262, Academic Press, New York.

Skoglund, U., K. Anderson, B. Bjorkroth, M.M. Lamb, and B. Daneholt. 1983. Visualization of the formation and transport of a specific hnRNP particle. Cell 34: 847-855.

Takagaki, Y., C.C. MacDonald, T. Shenk, and J.L. Manley. 1992. The $64 \mathrm{kD}$ polyadenylation factor contains an RNP-type RNA binding domain and unusual auxiliary motifs. Proc. Natl. Acad. Sci. 89: 1403-1407.

Theissen, H., M. Etzerodt, R. Reuter, C. Schneider, F. Lottspeich, P. Argos, R. Luhrmann, and L. Philipson. 1986. Cloning of the human cDNA for the U1 RNA-associated 70K protein. EMBO I. 5: 3209-3217.

Zahler, A.M., L.S. William, J.A. Stolk, and M.B. Roth. 1992. SR proteins: A conserved family of pre-mRNA splicing factors. Genes \& Dev. 6: 837-847.

Zamore, P.D., J.G. Patton, and M.R. Green. 1992. Cloning and domain structure of the mammalian splicing factor U2AF. Nature 355: 609-614.

Zink, B. and R. Paro. 1989. In vivo binding pattern of a transregulator of homoeotic genes in Drosophila melanogaster. Nature 337: 468-471.

Zuker, C.S., A.F. Cowman, and G.M. Rubin. 1985. Isolation and structure of a rhodopsin gene from $D$. melanogaster. Cell 40: $851-858$ 


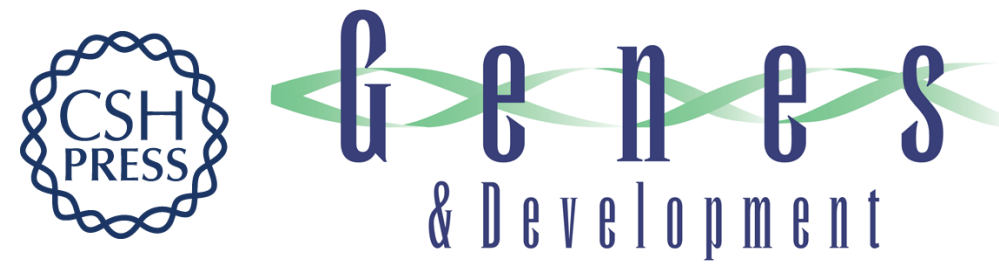

\section{The Drosophila RNA-binding protein RBP1 is localized to transcriptionally active sites of chromosomes and shows a functional similarity to human splicing factor ASF/SF2.}

Y J Kim, P Zuo, J L Manley, et al.

Genes Dev. 1992, 6:

Access the most recent version at doi:10.1101/gad.6.12b.2569

References This article cites 58 articles, 19 of which can be accessed free at:

http://genesdev.cshlp.org/content/6/12b/2569.full.html\#ref-list-1

License

Email Alerting Service

Receive free email alerts when new articles cite this article - sign up in the box at the top right corner of the article or click here.

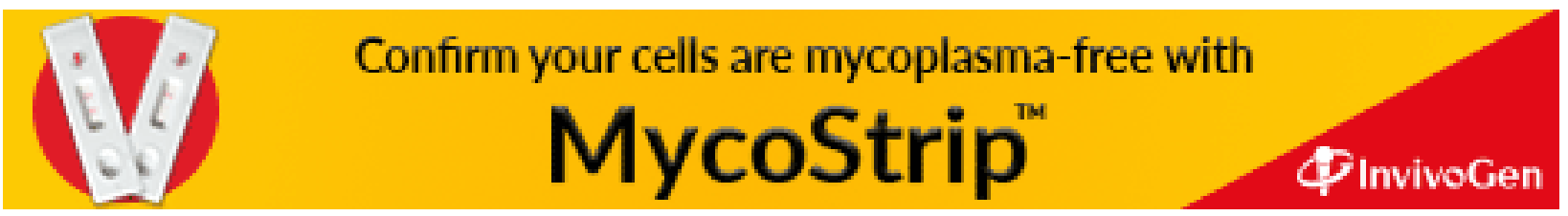

